\title{
Farklı aluviyal depozitler üzerinde gelişen toprakların pedolojik özelliklerinin belirlenmesi
}

\section{Determination of pedological properties of soils developed on different alluvial deposits}

\author{
Ozan ŞiMŞEK ${ }^{1}$ iD, Sevda ALTUNBAŞ ${ }^{*^{*}}$, Gafur GÖzÜKARA² ${ }^{\text {iD }}$, Bayram Çağdaş DEMiREL ${ }^{1}$ iD \\ ${ }^{1}$ Akdeniz Üniversitesi, Ziraat Fakültesi, Toprak Bilimi ve Bitki Besleme Bölümü, Antalya \\ ${ }^{2}$ Eskişehir Osmangazi Üniversitesi, Ziraat Fakültesi, Toprak Bilimi ve Bitki Besleme Bölümü, Eskişehir
}

To cite this article:

Şimşek, O., Altunbaş, S., Gözükara, G. \& Demirel, B.Ç.

(2020). Farklı aluviyal depozitler üzerinde gelişen toprakların pedolojik özelliklerinin belirlenmesi. Harran Tarım ve Gıda Bilimleri Dergisi, 24(3): 347 358.

DOI:10.29050/harranziraat.561651

Address for Correspondence: Sevda ALTUNBAŞ

e-mail:

saltunbas@akdeniz.edu.tr

Received Date:

08.05.2019

Accepted Date:

07.07.2020

() Copyright 2018 by Harran University Faculty of Agriculture. Available on-line at www.dergipark.gov.tr/harranziraat

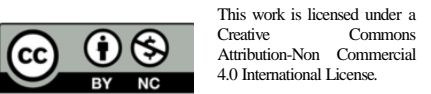

Öz

Akarsuların taşıdığı materyallerin depolandığı araziler üzerinde gelişen aluviyal topraklar birbirinden çok farklı özellikler göstermektedirler. Bu araştırma ile Antalya İli, Aksu ilçesine bağı Solak köyünde yer alan, Aluviyal toprakların seri bazında morfolojik, fiziksel ve kimyasal özelliklerinin tespit edilmesi ve serilerin yayılım alanlarının belirlenmesi amaçlanmıştır. Araştırma sonuçlarına göre; Taşkın düzlüğünde Batem 1, Ekspo, Mısnar, Körcegözler, Atçayırı, ve Kelbük serileri, nehir sırtı alüvyalleri üzerinde Solak serisi, yan dere Aluviyalleri üzerinde ise Batem 2 serileri tanımlanarak isimlendirilmiştir. Toprak profillerinden fiziksel ve kimyasal özelliklerinin belirlenmesi amacıyla 47 adet bozulmuş toprak örneği alınmıştır. Arazi ve laboratuvar bulguları sonucunda, çalışma alanı topraklarının zayıf strüktür gelişimi, düşük organik madde, yüksek kireç içeriği, yüksek kil ve zayıf drenaj problemlerinin olduğu tespit edilmiştir. Taşkın düzlüğü fizyoğrafyasında gelişen P2, P3 ve P5 profillerindeki yüksek kil içeriği, düşük geçirgenlik ve zaman zaman yükselen taban suları sorunlarına karşılık, nehir sırtı ve yan dere aluviyalleri üzerinde gelişen topraklarda göreceli olarak yüksek kum/silt içeriği ve düşük KDK sınırlamaları tespit edilmiştir. Araştırma sonuçlarına göre, tespit edilen 8 farklı toprak serisinde sınırlı toprak gelişimiyle $A / C$ horizon diziliminde olduğu ve çalışma alanı içerisinde en fazla yayılım alanına sahip toprak serisinin Kelbük (570.09 ha) en az yayılım alanına sahip toprak serinin ise Batem 2 (44.03 ha) olduğu tespit edilmiştir.

Anahtar Kelimeler: Aluviyal depozit, Toprak özellikleri, Toprak etüt ve haritalama

\section{ABSTRACT}

Aluvial soils that develop on the lands where the materials transported and deposited by the rivers show very different characteristics. The aim of this study was to determine the morphological, physical and chemical properties of alluvial soils as a soil series in Solak village of Aksu district of Antalya province and to determine the spriding areas of the soil series. According to the research results; Batem 1, Ekspo, Mısnar, Körcegözler, Atçayırı, and Kelbük series on the flood plains, the Solak series on the ridge alluviums and the Batem 2 series on the side stream alluvials were named. A total of 47 degraded soil samples were taken to determine the physical and chemical properties of the soil profiles. As a result of the field and laboratory findings, it was determined that the soils of the study area have limitationsof the study area had problems in the agricultural production due to weak structure development, low organic matter, high lime content, high clay and weak drainage. The high clay content, low permeability and occasionally rising ground waters in the P2, P3 and P5 profiles which developed in the flood plane physiography, while the relatively high sand/silt content and the low CEC content in the soils which developing on the ridge and side stream alluvials. According to the results of the research, all soil profiles determine as $\mathrm{A} / \mathrm{C}$ horizon sequence with limited soil development, and Kelbük (570.09 ha) soil series has been identified as most spread area, whereas Batem 2 (44.03 ha) soil series has been identified as least spread area in the study area.

Key Words: Alluvial deposits, properties of soil, soil survey and mapping 


\section{Giriş}

Tarım arazilerinin akılı kullanımı, ancak çok iyi bir planlama ile mümkün olabilir söz konusu planlamalar, toprak ve su kaynaklarının beraber değerlendirilmesi gereken, havza bazında yapılacak planlamalar ile ideal olacaktır. Tarım arazilerinin toprak özelliklerine bağlı olarak amacına uygun şekilde planlanıp kullanılması, topraklarımızın sürdürülebilirliği ve optimum su kullanımı açısından büyük bir önem arz etmektedir. Özellikle aluviyal tarım arazileri gerek ülkemiz ve gerekse dünya gıda güvenliği ve devamlılığı açısından stratejik bir öneme sahiptir (Şimşek ve ark., 2020).

Toprak oluşumu ve gelişimi için geçen zaman, toprakların özelliklerini ve onların ayrışma oranlarını belirler. Bu etki zamanla morfolojik, fiziksel, kimyasal ve mineralojik özelliklerin değişimi ve gelişimi ile değişik sayılarda horizonların oluşmasını ve farklılaşmasını sağlar (Sarı ve ark., 2003; Mutlu, 2010; Altunbaş ve Sarı, 2011; Gözükara, 2019: Gözükara ve ark., 2019; Gözükara ve ark., 2020). Toprakların sahip olduğu fiziko-kimyasal özellikleri oluşumlarının erken evrelerinde ana materyal tarafından kontrol edilirken, olgunluk dönemlerinde ayrışma ortamlarının diğer unsurlarının etkilerini ve buna bağlı değişim ve dönüşüm düzeylerini yansıtır. Buna göre zamanla vejetasyon, topoğrafya ve özellikle iklimin etkisiyle ortaya çıkan pedojenik süreçler, toprak kompozisyonunun ana materyalden farklılaşmasına neden olabilir (Mutlu, 2010). Bu farklılaşma başlangıç olarak elementlerin toprak profili içinde yeniden dağılımı, horizonlaşma ve son olarak da bu dağılıma bağlı olarak toprak tiplerinin farklılaşması olarak ortaya çıkar (Jenkins ve Jones, 1980). Ancak toprak oluşumu için geçen zaman aynı olsa bile diğer toprak yapan faktörlerin etkisi ile toprakların morfolojisi ve fiziko-kimyasal özellikleri farklılık gösterebilir (Dinç ve ark., 1990; Osher, 1998; Mutlu, 2010; Sarı, 2015; Owliaie ve ark., 2018; Gözükara ve ark., 2019; Gözükara ve ark., 2020). Halen çeşitli değişim ve dönüşüm süreçlerini yaşamakta olan yeryüzü, bu günkü görünümüne ulaşıncaya kadar pek çok jeolojik ve jeomorfolojik olayın etkisinde kalmıştır. Bu süreçler içerisinde bazı alanlar geniş veya dar, derin veya yüzlek, durgun veya akan su kütlelerinin etkisi altında gelişimlerinin sürdürmüşlerdir (Gözükara ve ark., 2019; Gözükara ve ark., 2020). Akarsular tarafından oluşturulmuş (fluviyal) yer şekillerinin diğer jeomorfolojik güçler tarafından oluşturulanlar arasında özel bir yeri vardır (Şenol, 2000). Devamlı buzullarla kaplı alanlar ve pek az yağış alan çöl bölgeleri dışında kalan yer şekillerinin önemli bir kısmı akarsular tarafından oluşturulmuştur. Bu nedenle akarsuları, yeryüzü şekillerini değiştiren ve ona yeni şekiller veren en etkin jeomorfolojik güç olarak tanımlamak mümkündür (Şenol, 2000). Akarsuların yeryüzünü şekillendirmede etkili olan faaliyetleri ise bir havza içerisindeki farklı zonlarda-konumlarda meydana gelmekte olan "aşındırma, taşıma ve depolama" faaliyetleridir. Akarsular akış güzergahları boyunca yatak çevresinden ve ayrıca akarsuya bağlanan irili ufaklı binlerce yan kollarının yaptığı aşındırma ve koparmalar neticesinde tonlarca ağırlıkta ve çok çeşitli irilikteki materyalleri (kaya, taş, çakıl toprak vd) akış debisi ve hızları doğrultusunda sürüklerler. Akarsuların hızının ve taşıma gücünün azaldığı herhangi bir yerde bu materyalleri depolamaktadır (Sarı, 2015). Dolaysıyla, akarsuların zamanla taşıdığı depozitlerin boyutlarına ve özelliklerine bağlı olarak oluşmuş aluviyal arazilerde kısa mesafelerde dahi çok farklı özelliklerde topraklar oluşabilmektedir (Sarı ve ark., 2003; Sarı ve ark., 2009; Dengiz ve Gülser, 2014; Gözükara, 2019). Bu toprakların fiziksel, kimyasal ve morfolojik özellikleri, aluviyal ana materyalin özelliği, taşınma ve birikme sırasında meydana gelen değişmeler sonucu çok kompleks bir oluşum göstermektedirler. İşte, her türlü arazi kullanımı ve toprak yönetimine ilişkin kararların doğru verilebilmesi açısından söz konusu bu faaliyetlerin yani "aşındırma-taşıma-depolama" olaylarının ortaya çıkarmış olduğu arazi ve toprakların ayrıntılı olarak incelenmesi gerekmektedir (Sarı, 2015).

$\mathrm{Bu}$ araştırma ile Antalya İli, Aksu ilçesine bağlı 
Solak köyünde yer alan, Aluviyal toprakların seri bazında morfolojik, fiziksel ve kimyasal özelliklerinin tespit edilmesi ve serilerin yayılım alanlarının belirlenmesi amaçlanmıştır.

\section{Materyal ve Yöntem}

\section{Materyal}

Türkiye'nin güneyinde yer alan çalışma alanı, Antalya îli Aksu ilçesi sınırları içerisindedir (Şekil 1). DSi 13. Bölge Müdürlüğü tarafından yürütülen, Aksu Çayı Taşkın Koruma ve Arazi Toplulaştırma Projesi kapsamında bulunan Solak Köyü arazileri araştırma kapsamında materyal olarak seçilmiştir. Araştırma alanı Antalya il merkezine yaklaşık 20 km (Solak Köyü) uzaklıkta, 3052'11" ile 3054'17" doğu boylamları ve $36^{\circ} 56^{\prime} 11^{\prime \prime}$ ile $36^{\circ} 58^{\prime} 38^{\prime \prime}$ kuzey enlemleri arasında 1625 ha büyüklüğündedir. Çalışma alanı Antalya havzasının sahil kesimindeki tipik Akdeniz iklim kuşağında yer almaktadır. Bu kuşakta yazlar sıcak ve kurak kışlar ılık ve yağışı geçmektedir. Yıllık ortalama yağış miktarı 1068 mm olup yağışlar yağmur şeklinde ve çoğunlukla ilkbahar ve kış aylarında düşmektedir. Yıllık ortalama sıcaklık ise $18.4{ }^{\circ} \mathrm{C}^{\prime}$ dir. Toprak taksonomisine göre (Soil Survey Staff, 2014) araştırma alanının toprak nem rejimi Xeric, $50 \mathrm{~cm}$ 'deki yıllık ortalama toprak sıcaklığının $15-22{ }^{\circ} \mathrm{C}$ arasında olması nedeniyle toprak sıcaklık rejimi de Thermic olarak sınıflandırılmıştır.Araştırma alanı, günümüzde de aktif olan başta Aksu Çayı olmak üzere diğer birkaç küçük akarsuyun binlerce yıl önceki taşkınları sonucunda kuzeydeki Toros Dağlarından taşıyarak getirdiği ve çoğunluğu kireçce zengin jeolojik materyallerin birikip depolanması sonucu oluşan bir yapı arzetmektedir.

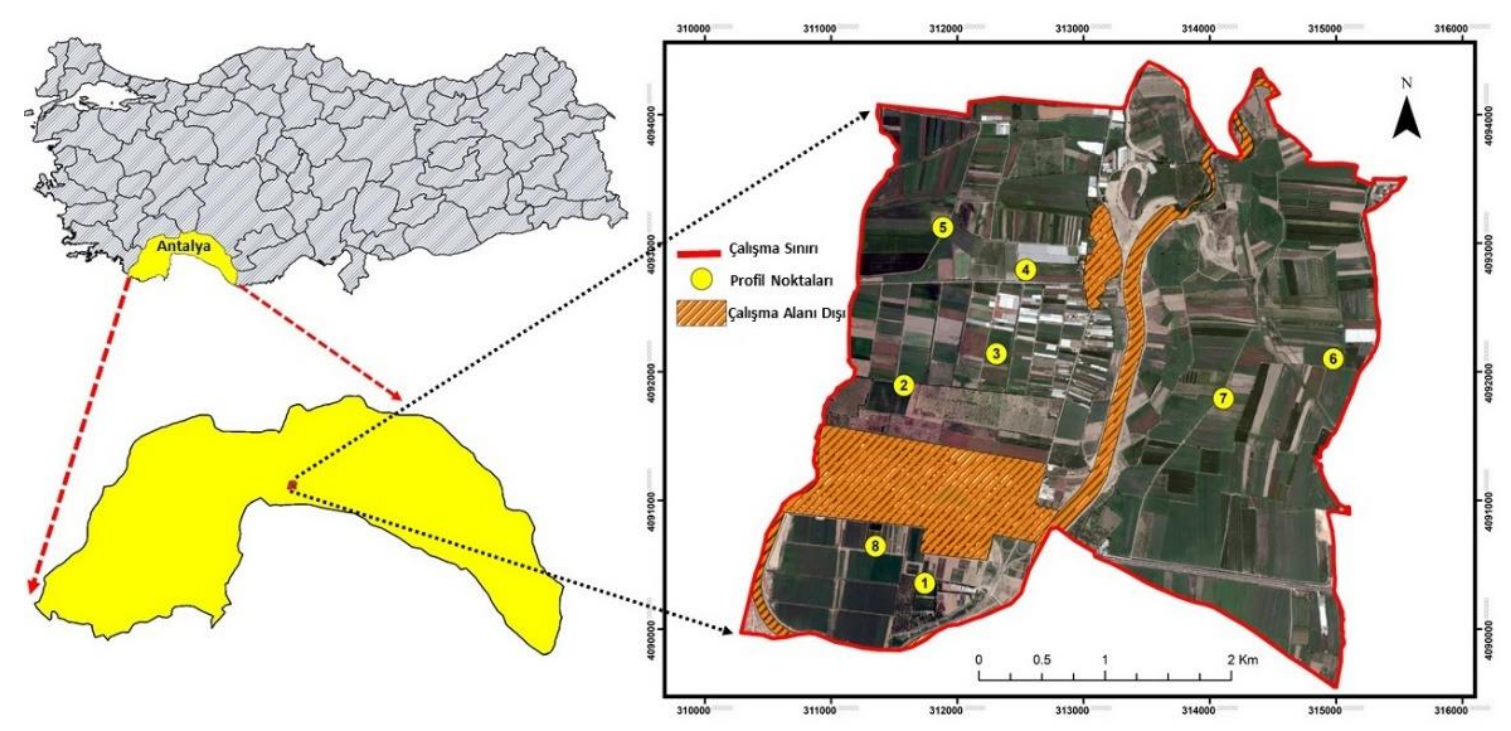

Şekil 1. Çalışma alanının coğrafik konumu ve profil noktalarının dağılımı Figure 1. Geographical location of the study area and distribution of profile points

\section{Yöntem}

Araştırma metod olarak, büro çalışmaları, arazi çalışmaları ve laboratuvar çalışmaları olmak üzere üç aşamada gerçekleştirilmiştir. Aşağıda metodu oluşturan her bir aşama maddeler halinde verilmiştir.

\section{Büro çalışmaları}

Bu araştırma, Toprak Genetiği ve Toprak Etüt Haritalama Biliminin esasları (Soil Survey Staff,
2014) dahilinde başta olmak üzere uzaktan algılama ve coğrafi bilgi sistemlerinden yararlanılarak yürütülmüştür. $\mathrm{Bu}$ çalışmada Aluviyal arazilerdeki mekansal farklılıklara göre profil noktalarının yerlerinin tespit edilmesinde temel kartografik materyal olarak; Harita Genel Komutanlığı (HGK) tarafından üretilen 1/25000 ölçekli topografik haritalar, Maden Tetkik Arama Genel Müdürlüğü (MTA) tarafından üretilen $1 / 25000$ ve $1 / 100000$ ölçekli jeoloji haritaları, 
Tapu Kadastro Genel Müdürlüğü (TKGM) tarafından üretilen ortofotolar $(30 \mathrm{~cm}$ çözünürlüklü), 1981 ve 1992 yıllarına ait hava fotoğrafları ile 2016 tarihli Sentinel uydu görüntüsü $(10 \mathrm{~m})$, materyal olarak kullanılmıştır. Bu kartografik materyaller kullanılarak çalışma alanında yayılım gösteren farklı fizyografik üniteler, rölyef, bakı ve arazi şekilleri belirlenmiştir. Böylece belirlenen ana materyaldeki farklılıklar ve farklı fizyografya üzerinde oluşmuş olası toprak seri haritası oluşturulmuştur. Araştırma sonucunda elde edilen verilerden sayısal veri tabanı ile tematik haritaların oluşturulması aşamasında ArcGIS 10.2 yazılımından faydalanılmıştır.

\section{Arazi çalışmaları}

Kartoğrafik materyallerin değerlendirilmesi ile oluşturulan taslak toprak haritasında nehir sırtı, taşkın düzlüğü ve taşkın düzlüğüne bağlanan yan dere Aluviyalleri fizyoğrafik ünitelerine ait 8 adet profil noktası belirlenmiştir. Arazi kontrolleri yapıldıktan sonra belirlenen noktalardan profil çukurları açılarak, 8 farklı toprak serisi tespit edilmiştir. Toprakların fiziksel ve kimyasal özelliklerini bulmak amacı ile 8 profilin her bir farklı horizonu Soil Survey Staff (2014) esasları dahilinde morfometrik-genetik yaklaşımla tanımlanarak sınıflandırılmıştır (Çizelge 1). Arazi şartlarında her bir profilde genetik horizon esasına göre yapılan morfolojik tanımlamalarda; horizonların alt ve üst sınırları, horizonlar arası sınır özellikleri, renk, tekstür, strüktür, kıvam, kireç içeriği, kök dağılımı, taşlılık, gözeneklilik ve diğer özel görünümler (kayma yüzeyleri, kireç birikimleri, kütan, vb.) dikkate alınarak tanımlanmıştır (Hızalan, 1969; Soil Survey Staff, 2013; Dinç ve Şenol, 2013). Morfolojik tanımlamalarda \%10'luk $\mathrm{HCl}$, Munsell renk skalası, şerit metre ve x30, x100 el büyüteci kullanılmıştır (Soil Survey Staff, 2013; Dinç ve Şenol, 2013). Morfolojik tanımlamaları yapılmış olan her bir horizondan fiziksel ve kimyasal analizlerde kullanılmak amacıyla 46 adet toprak örneği alınmıştır.

\section{Laboratuvar çalışmaları}

Çalışma alanında farklı fizyografyaları temsil eden toprakların özelliklerini belirlemek için açılan profillerden, genetik horizon esasına göre alınan bozulmuş toprak örnekleri, laboratuvarda analize alınmadan önce oda sıcaklığında hava kuru hale getirildikten sonra $2 \mathrm{~mm}$ 'lik elekten elenerek analizler için uygun hale getirilmiştir. Toprak örneklerinde, toprak tekstürü Bouyoucos (1955) tarafından belirlenen esaslara göre hidrometre yöntemiyle yapılmıştır. Organik madde (Black, 1965), toprak reaksiyonu $(\mathrm{pH})$ ve Elektriksel iletkenlik (EC) Jackson (1967)'a göre 1:2.5 topraksu karışımında $\mathrm{pH}$ metre aleti kullanılarak ölçülmüştür. Toprak örneklerinin kireç $\left(\mathrm{CaCO}_{3}\right)$ içerikleri Scheibler Kalsimetresi ile ölçülmüş (Evliya, 1964). Katyon değişim kapasitesi (KDK) 1 $\mathrm{N}$ amonyum asetat yöntemine göre belirlenmiştir (Soil Survey Laboratory, 2004). Değişebilir katyonlar (DK) $1 \mathrm{~N}$ amonyum asetat yöntemine göre belirlenmiştir (Kacar, 1995).

Veri tabanının ve seri dağılım haritasının oluşturulması

Verilerin CBS ortamında analiz edilebilmesi için 259 farklı kontrol noktasından (Şekil 2) elde edilen seri değerleri sayısal ortamda öznitelik verisi olarak eklenmiştir. Verilerin değerlendirilerek toprak serilerinin dağılım haritasının oluşturulması aşamasında ArcGIS 10.2 yazılımında Jeoistatistik Analiz modülü kullanılmıştır. Bu modül içerisinde ordinary kriging enterpolasyon ve üssel model ile (Exponatial) toprak serilerinin dağılım haritası oluşturulmuştur. Enterpolasyonlar sonucu otomatik olarak tahmin edilen değerler ile ölçülen değerler ve arasındaki ilişkiyi sorgulayarak ölçülen değerlere en yakın sonucu veren en düşük Ortalama Hata Kareleri Toplamının Karekökü (RMSE) değeri referans olarak alınmıştır. 
Çizelge 1. Toprak profillerinin özellikleri Table 1. Properties of soil profiles

\begin{tabular}{|c|c|c|c|c|c|c|c|}
\hline $\begin{array}{l}\text { Profil } \\
\text { Profile }\end{array}$ & $\begin{array}{l}\text { Seri İsmi } \\
\text { Series } \\
\text { Name }\end{array}$ & $\begin{array}{l}\text { Konum } \\
\text { Location }\end{array}$ & $\begin{array}{l}\text { Yükseklik } \\
\text { Altitude }\end{array}$ & $\begin{array}{c}\text { Toprak } \\
\text { Sınıflama } \\
\text { Soil } \\
\text { Taxonomy } \\
\end{array}$ & $\begin{array}{c}\text { Fizyografya } \\
\text { Psychographic } \\
\text { Units }\end{array}$ & $\begin{array}{c}\text { Ana } \\
\text { Materyal } \\
\text { Parent } \\
\text { Material }\end{array}$ & $\begin{array}{l}\text { Arazi } \\
\text { Kullanımı } \\
\text { Land } \\
\text { Use }\end{array}$ \\
\hline 1 & Batem 1 & $\begin{array}{l}36^{\circ} 56^{\prime} 26.14^{\prime \prime K} \\
30^{\circ} 53^{\prime} 90.64^{\prime \prime D}\end{array}$ & $9 \mathrm{~m}$ & Haploxerepts & $\begin{array}{c}\text { Taşkın } \\
\text { Düzlüğü }\end{array}$ & $\begin{array}{l}\text { Kireçli } \\
\text { Killer }\end{array}$ & Narenciye \\
\hline 2 & Ekspo & $\begin{array}{l}36^{\circ} 57^{\prime} 11.47^{\prime K} \mathrm{~K} \\
30^{\circ} 52^{\prime} 58.37 " \mathrm{D}\end{array}$ & $9 \mathrm{~m}$ & Haploxerepts & $\begin{array}{l}\text { Taşkın } \\
\text { Düzlüğü }\end{array}$ & $\begin{array}{l}\text { Kireçli } \\
\text { Killer }\end{array}$ & Misır \\
\hline 3 & Misnar & $\begin{array}{l}36^{\circ} 57^{\prime} 22.40^{\prime \prime} \mathrm{K} \\
30^{\circ} 53^{\prime} 25.59^{\prime \prime} \mathrm{D}\end{array}$ & $9 \mathrm{~m}$ & Haploxerepts & $\begin{array}{c}\text { Taşkın } \\
\text { Düzlüğü }\end{array}$ & $\begin{array}{l}\text { Kireçli } \\
\text { Killer }\end{array}$ & Nar \\
\hline 4 & Körcegözler & $\begin{array}{l}36^{\circ} 57^{\prime} 43.81^{\prime \prime} \mathrm{K} \\
30^{\circ} 53^{\prime} 54.60^{\prime \prime} \mathrm{D}\end{array}$ & $10 \mathrm{~m}$ & Haploxerepts & $\begin{array}{c}\text { Taşkın } \\
\text { Düzlüğü }\end{array}$ & $\begin{array}{l}\text { Kireçli } \\
\text { Killer }\end{array}$ & Misır \\
\hline 5 & Atçayırı & $\begin{array}{l}36^{\circ} 57^{\prime} 57.63^{\prime \prime} \mathrm{K} \\
30^{\circ} 53^{\prime} 57.63^{\prime \prime D}\end{array}$ & $10 \mathrm{~m}$ & Endoaquepts & $\begin{array}{l}\text { Taşkın } \\
\text { Düzlüğü }\end{array}$ & $\begin{array}{l}\text { Kireçli } \\
\text { Killer }\end{array}$ & Misır \\
\hline 6 & Kelbük & $\begin{array}{l}36^{\circ} 57^{\prime} 25.36^{\prime \prime} \mathrm{K} \\
30^{\circ} 55^{\prime} 27.45^{\prime \prime} \mathrm{D}\end{array}$ & $10 \mathrm{~m}$ & Haploxerepts & $\begin{array}{l}\text { Taşkın } \\
\text { Düzlüğü }\end{array}$ & $\begin{array}{l}\text { Kireçli } \\
\text { Killer }\end{array}$ & Pamuk \\
\hline 7 & Solak & $\begin{array}{l}36^{\circ} 57^{\prime} 16.63^{\prime \prime K} \\
30^{\circ} 54^{\prime} 45.31^{\prime \prime D}\end{array}$ & $10 \mathrm{~m}$ & Haploxerepts & Nehir Sırtı & $\begin{array}{l}\text { Kireçli } \\
\text { Killer }\end{array}$ & Pamuk \\
\hline 8 & Batem 2 & $\begin{array}{l}36^{\circ} 56^{\prime} 26.10^{\prime \prime} \mathrm{K} \\
30^{\circ} 53^{\prime} 03.35^{\prime \prime D}\end{array}$ & $12 \mathrm{~m}$ & Haploxerepts & $\begin{array}{c}\text { Yan dere } \\
\text { Aluviyalleri }\end{array}$ & $\begin{array}{l}\text { Kireçli } \\
\text { Killer }\end{array}$ & Misır \\
\hline
\end{tabular}

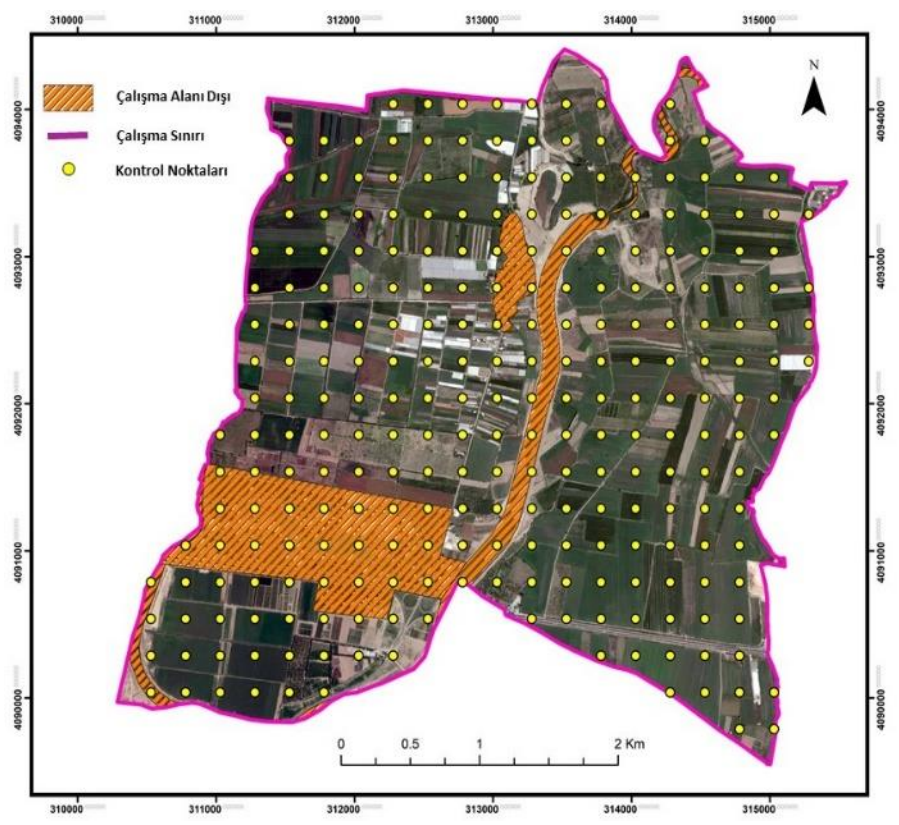

Şekil 2. Çalışma alanı içerisinde yayılım gösteren toprak serilerinin sınırlarını kesinleştirmede kullanılan kontrol noktaları Figure 2. Control points used to determine the boundaries of the soil series spreading within the study area

\section{Araştırma Bulguları ve Tartışma}

Hava fotoğrafları ve uydu görüntülerinin yorumlamaları ile arazi çalışmalarından elde edilen verilerin değerlendirilmesi sonucunda çalışma alanının baskın olarak Aksu Çayı ve bazı bölgelerde de Tehnelli Deresinin taşıyıp biriktirdiği materyaller ile oluştuğu tespit edilmiştir. Çalışma sınırlarımız içindeki Aluviyal arazilerde temelde nehir sırtı ve taşkın düzlüğü fizyoğrafik üniteleri yer alırken, çalışma alanının kuzey doğusunda da taşkın düzlüklerine bağlanan yan dere Aluviyalleri adı altında bir diğer fizyoğrafik ünite belirlenmiştir. Bu fizyografik üniteler üzerinde ise birbirinden farklı sekiz toprak çeşidinin olduğu tespit edilmiştir. Kuvaterner yaşlı Aluviyal depozitler üzerinde gelişen bu topraklar yaklaşık 9-12 m yüksekliklerde ve düz düze yakın alanlarda yayılım göstermektedir. Farklı toprak çeşitlerinin morfolojik, fiziksel ve kimyasal özelliklerinin belirlenmesinde kullanılan bozulmuş toprak örneklerinin alındığı toprak profillerinin konumları ile birlikte horizonları Şekil 3'de gösterilmiştir. Aşağıda her bir fizyoğrafik ünite ve bu fizyoğrafik üniteler üzerinde yer alan farklı toprak serilerine ilişkin tüm morfolojik, fiziksel ve kimyasal özellikler verilmiştir. 


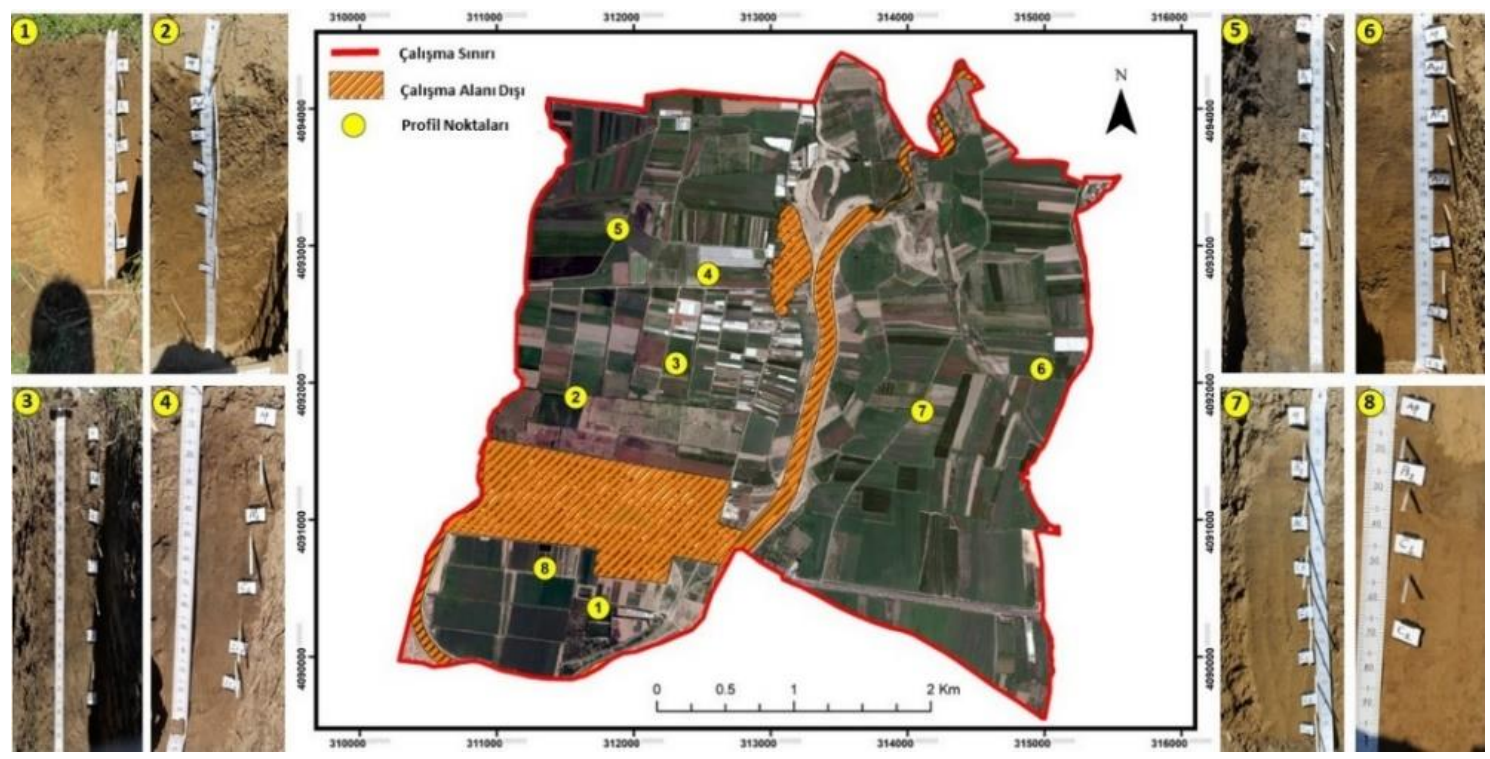

Şekil 3. Çalışma alanı içerisindeki profillerin dağılımı ve horizonları

Figure 3. Distribution and profiles within the study area

Akarsular, bazı dönem taşıyabileceklerinden daha fazla suyu alırlar ve bunları yataklarının sağında ve solunda yer alan, akarsu setlerini aşırıp daha uzak ve akarsu setlerine oranla daha çukur bir topoğrafyaya sahip, taşkın düzlüklerine depolarlar. Küçük veya büyük her akarsuyun bir taşkın düzlüğü vardır. Küçük akarsuların dar taşkın düzlükleri bulunurken büyük akarsuların taşkın düzlükleri ise binlerce kilometre genişliğinde olabilir. Derin ve dar vadiler içinden akan akarsuların, taşkın düzlükleri çok küçüktür ya da hiç yoktur. Bazı taşkın düzlükleri çoğunlukla uç seti şeklinde çökelmiş olan kum ve çakıldan oluşurken genel olarak taşkın düzlükleri kil, siltli kil gibi ince tekstürlü topraklardan oluşur.

Araştırma alanında taşkın düzlüğü toprakları, Aksu Çayı ve Tehnelli derelerinin yakın geçmişe kadar yaptığı taşkınlar sonucu, taşıyıp depoladığı ve genel olarak farklı tekstür özelliklere sahip, kireçli birikimlerdir. Bu araziler Kuvaterner Dönemin ürünleri olduklarından göreceli olarak genç oluşumlardır. Bu nedenle profilleri boyunca $A$ ve $C$ horizonları dışında başka tanımlayıcı horizonları henüz gelişememiştir. Bu fizyoğrafik ünitede yer alan serilerin tamamı düz ve düze yakın arazilerdir. Depolanan Aluviyal materyalin tekstürünün ince olması ve düz topoğrafyalarda bulunmaları nedeniyle bu fizyoğrafik ünite üzerinde yer alan toprak serilerinin bazılarında hafiften şiddetliye kadar değişen düzeylerde drenaj problemi bulunmaktadır. Taşkın düzlügünde yer alan toprak serileri, Batem 1 (Bt1), Ekspo (Ek), Mısnar (Mn), Atçayırı (Aç), Kelbük (Kb) ve Körcegözler $(\mathrm{Kg})$ serileridir. Söz konusu toprak serilerinin morfolojik özellikleri ile fiziksel ve kimyasal analiz sonuçları Çizelge 2 ve Çizelge 3'de verilmiştir.

Akarsuların aşındırma, taşıma ve depolama özellikleri neticesinde oluşturulan Aluviyal araziler (nehir sırtları, taşkın düzlükleri, yan dere Aluviyalleri) yakın jeolojik dönemlerde oluştuklarından $A / C$ profil dizilimi göstermektedirler. Söz konusu taşkın düzlüğü fizyoğrafik ünitesinde de beklendiği şekilde A-C dizilimli topraklar tespit edilmiştir. Bu fizyoğrafik ünite üzerinde yer alan toprak serilerinde renk, farklı taşkın zamanlarındaki depolanmaya bağlı olarak değişiklik göstermektedir(2.5Y 3/1 - 10YR $5 / 4)$. Derin profillere sahip olan seri topraklarında A horizonlarında strüktür genellikle yarı köşeli veya köşeli blok iken, $C$ horizonlarında da masif olarak belirlenmiştir. Kıvam özellikleri ise içerdikleri kil miktarındaki artışla nemli iken sıkı, yaş iken yapışkan veya çok yapışkan çok plastik olarak tespit edilmiştir (Çizelge 2). Yakın jeolojik dönemlerde taşınıp çökeldiklerinden dolayı tüm profillerin kireçli olduğu ve düzenli ve düşük enerjili taşkınlar neticesinde de horizonlar arasındaki sınırın belirgin düz olduğu görülmüştür. Taşkın düzlüğünde yer alan profillerde $\mathrm{pH}$ nötr ve hafif alkali düzeyindedir. Kireç içerikleri incelendiğinde ise genel olarak profillerde yukardan aşağı bir kireç yıkanımı olması 
beklenirken, sadece P3 ve P5 profillerinin A horizonlarından $C$ horizonlarına doğru kireç yıkanımının (yani pedolojik bir değişim dönüşüm işleminin, kalsifikasyon/ dekalsifikasyon) gerçekleşmiş olduğu görülmektedir. Yukarıdaki tespitlerden de anlaşılacağı üzere Kuvaterner yaşlı taşkın düzlükleri üzerinde yer alan P3 ve P5 profillerinde belli düzeylerde bir profil gelişiminin yaşanmış olduğu, ancak bu oluşumun B horizonunun gelişimi gibi ileri düzeyde bir toprak oluşumuna sahip olacak kadar zaman geçmediğini bir diğer ifade ile çok genç olduklarını göstermektedir. Ayrıca topraklarda kireç yıkanımının net bir şekilde gözlenememesi ve taşkın dönemlerinde, farklı kireç içerikli materyallerin depolanması sonucu profillerdeki kireç içeriğinin düzensiz bir dağılım göstermesi de bu toprakların genç olduğu bulgumuzu doğrulamaktadır. Tuzluluk profillerin tamamında \%0.006-0.111 arasında değişmesinden dolayı profillerde herhangi bir tuzluluk tehlikesi bulunmamaktadır. Organik madde yüzey horizonlarında düşük veya yeterli düzeylere bulunurken, profil boyunca aşağı doğru azalarak çok düşük seviyelerine ulaşmaktadır. Toprak tekstür özellikleri ise neredeyse tüm profillerde SiC veya $C$ tekstürlü iken, Kelbük ve Batem 1 serilerinde ağırlıklı olarak $\mathrm{SiCL}$ ve $\mathrm{CL}$ tekstüre de rastlanılmıştır. Değişebilir katyonlar içerisinde ağırlıklı olarak Ca ve Mg iyonlarının baskın olduğu belirlenmiştir.

Araştırma alanında yer alan nehir sırtı toprakları, Aksu Çayı ve Tehneli derelerinin yakınlarında yayılım göstermektedirler. Söz konusu bu derelerin zamanla getirdiği materyallerin, yataklarının sağ ve sol sahillerinde depolanmaları sonucunda oluşmuş, kireçli ve genç depozitlerdir. Profilleri $\mathrm{A}$ ve $\mathrm{C}$ horizonludur. $\mathrm{Bu}$ araziler düz-düze yakın eğimde olup, geçirgenlikleri de oldukça yüksektir. Bu nedenle bu topraklar tekstürlerinin kaba olması nedeni ile drenaj problemi yaşamamaktadırlar. Bu fizyografik ünite üzerinde Solak (SI) serisi yer almaktadır. Bu ünite üzerindeki topraklarda renk, 2.5 Y 5/3-10 YR 4/3 arasında değişmektedir. Derin profil dizilimine sahiptirler. Strüktürel dağılımları ise A horizonlarında yarı köşeli blok ve granüler iken C horizonlarında ise masiftir. Kıvam, kuru iken sert, nemli iken sıkı, yaş iken düşük kil içeriğine bağlı olarak, az yapışkan az plastik veya yapışkan değil plastik değil bulunmuştur (Çizelge 2). Tüm profillerde horizonlar arasındaki sınır belirgin düzdür. Solak serisinin yayılım gösterdiği alanlarda yer alan topraklarda tekstür olarak L, $\mathrm{SCL}, \mathrm{SiL}, \mathrm{SC}$ ve SiC olarak tespit edilmiştir (Çizelge 2). $\mathrm{pH}$ içerikleri 7.37-7.68 arasında nötr ile hafif alkali arasındadır. Kireç içeriği ise profilin tüm katmanlarında aşırı kireçli olup \%31.14-34.25 arasında değişim göstermektedir (Çizelge 3). Toprakların yakın jeolojik devirlerde oluşmuş olması ve sık sık yeni taşkınlar sonucunda yeni materyallerin depolanması kirecin profilden yıkanıp uzaklaşmasına yetecek zamanı tanıyamamıştır.Bu ünite üzerindeki toprakların organik madde içerikleri, yüzey horizonunda daha yüksek iken, alt katmanlarda azalarak çok düşük düzeylere ulaşmıştır. Fakat profilin genelinin organik madde içeriği diğer fizyografik üniteler üzerinde gelişen topraklara göre göreceli olarak daha fazladır. Tuzluluk tüm profilde çok düşük düzeylerde olup, tuzluluk tehlikesi bulunmamaktadır. Zira hafif tekstürlü olması da, profillerde tuz ve diğer iyonların zayıf tutunmasına neden olmaktadır. Değişebilir katyonlar içerisinde Ca ve $\mathrm{Mg}$ baskın olup, KDK ise taşkın düzlüğü topraklarındaki kadar yüksek kil ve OM ye sahip olmaması sebebi ile daha düşüktür.

Traverten düzlükleri üzerine, Aksu Çayı́nın depozitleri birikerek depolanmıştır. Yakın gelecekte ve günümüzde ise yüksek arazilerden kısa mesafelerde taşınan yan dereler bu depozitleri, farklı nitelikte, yeni depozitler ile doldurarak, taşkın düzlüklerine bağlanan yan dere Aluviyallerini oluşturdukları gözlemlenmiştir. Bu ünite üzerinde Batem 2 (Bt2) serisi yer almaktadır. Genç Aluviyal depozit olmaları nedeniyle $A / C$ horizon dizilimine sahip olan bu ünitede toprak derinliği orta derinliktedir. Horizonlar arasında belirgin düz sınır tespit edilmiştir. Renk 10 YR 4/3 ve 10 YR 4/4'dür. Strüktür; A horizonunda yarı köşeli blok, $C$ horizonlarında ise masiftir. Kıvam özellikleri, kil miktarına bağı olarak, kil içeriğinin yüksek olduğu katmanlarda kuru iken sert, nemli iken sıkı ve yaş iken de çok yapışkan çok plastik, kil 
içeriğinin düşük olduğu katman ve profillerde ise yapışkan değil plastik değil olarak tespit edilmiştir.

$\mathrm{Bu}$ fizyoğrafik ünite üzerinde yer alan toprakların pH içerikleri, $7.43-7.48$ arasında hafif alkalidir. Tuzluluk problemi bulunmayan topraklarda, kireç miktarları düzenli bir dağılım göstermemekte, yüksek ve aşırı kireçli bir yapı arz etmektedir. OM içerikleri genel olarak profillerin üst katmanlarında yüksek iken alt katmanlara doğru azalarak düşük veya çok düşük düzeylere ulaşmıştır. Değişebilir katyonlar içerisinde Ca ve $\mathrm{Mg}$ baskın iken KDK kil içeriği yüksek olan katmanlarda nispeten daha yüksektir. Tekstür; tüm profil boyunca $\mathrm{CL}^{\prime}$ dir. Bu fizyoğrafik ünitedeki toprakların fosfor içeriği yüksek düzeyde bulunmaktadır. Profillerde fosfor yüksek çıksa bile alkali $\mathrm{pH}$ ve kireç içeriğinin yüksek olması sebebiyle bitkilerde fosfor beslenmesinde sorun yaşanmaktadır.

Çizelge 2. Toprak profillerin morfolojik ve fiziksel özellikleri

Table 2. Morphological and physical properties of soil profiles

\begin{tabular}{|c|c|c|c|c|c|c|c|c|}
\hline $\begin{array}{l}\text { Profil } \\
\text { Profile }\end{array}$ & $\begin{array}{l}\text { Horizon } \\
\text { Horizon }\end{array}$ & $\begin{array}{c}\text { Derinlik } \\
\text { (cm) } \\
\text { Depth } \\
(\mathrm{cm}) \\
\end{array}$ & $\begin{array}{l}\text { Renk } \\
\text { (Yaş) } \\
\text { Color } \\
\text { (wet) }\end{array}$ & $\begin{array}{c}\text { Strüktür ve } \\
\text { Yaş Kıvam } \\
\text { Structure and } \\
\text { Wet vis }\end{array}$ & $\begin{array}{c}\text { Kum } \\
(\%) \\
\text { Sand } \\
(\%)\end{array}$ & $\begin{array}{l}\text { Silt } \\
(\%) \\
\text { Silt } \\
(\%) \\
\end{array}$ & $\begin{array}{l}\text { Kil } \\
\text { (\%) } \\
\text { Clay } \\
(\%) \\
\end{array}$ & $\begin{array}{l}\text { Tekstür } \\
\text { Texture }\end{array}$ \\
\hline \multirow{5}{*}{ P1 } & Ap & $0-14$ & $2.5 Y 3 / 2$ & KOYKB; Y-P & 13.88 & 44.85 & 41.27 & sic \\
\hline & $\mathrm{A} 2$ & $14-31$ & $2.5 Y 3 / 2$ & KOYKB; ÇY-ÇP & 14.52 & 43.28 & 42.20 & sic \\
\hline & $A C$ & $31-49$ & $2.5 Y 3 / 2$ & Masif; Y-P & 13.52 & 48.21 & 38.27 & SICL \\
\hline & $\mathrm{C} 1$ & $49-75$ & $2.5 Y 4 / 3$ & Masif; Y-P & 15.52 & 48.92 & 35.56 & SICL \\
\hline & $\mathrm{C} 2$ & $75+$ & $2.5 Y 4 / 3$ & Masif; Y-P & 27.52 & 40.92 & 31.56 & $\mathrm{CL}$ \\
\hline \multirow{6}{*}{ P2 } & Ap & $0-17$ & $10 Y R 4 / 3$ & OOYKB; ÇY-ÇP & 0.52 & 45.68 & 53.8 & sic \\
\hline & $\mathrm{A} 2 \mathrm{~d}$ & $17-26$ & $10 Y R 4 / 3$ & OOYKB; ÇY-ÇP & 3.52 & 35.28 & 61.2 & $\mathrm{C}$ \\
\hline & $\mathrm{AC}$ & $26-42$ & 10YR 4/4 & Masif; ÇY-ÇP & 3.52 & 34.28 & 62.2 & C \\
\hline & $\mathrm{C} 1$ & $42-66$ & $2.5 Y 5 / 3$ & Masif; ÇY-ÇP & 6.52 & 34.21 & 59.27 & C \\
\hline & $\mathrm{C} 2$ & $66-108$ & $2.5 Y 4 / 4$ & Masif; ÇY-ÇP & 3.88 & 23.92 & 72.2 & C \\
\hline & $\mathrm{C} 3$ & $108+$ & $2.5 Y 4 / 4$ & Masif; ÇY-ÇP & 0.88 & 20.92 & 78.2 & $\mathrm{C}$ \\
\hline \multirow{6}{*}{ P3 } & $A p$ & $0-18$ & $2.5 Y 4 / 2$ & OOYKB; ÇY-ÇP & 3.88 & 39.56 & 56.56 & $\mathrm{C}$ \\
\hline & $A 2 d$ & $18-38$ & $2.5 Y 4 / 2$ & ZOYKB; ÇY-ÇP & 4.88 & 43.92 & 51.20 & sic \\
\hline & $A C$ & $38-58$ & $2.5 Y 4 / 3$ & Masif; ÇY-ÇP & 8.16 & 33.64 & 58.20 & $\mathrm{C}$ \\
\hline & $\mathrm{C} 1$ & $58-77$ & $2.5 Y 4 / 2$ & Masif; ÇY-ÇP & 8.88 & 32.92 & 58.20 & C \\
\hline & $\mathrm{C} 2$ & $77-108$ & $2.5 Y 4 / 2$ & Masif; ÇY-ÇP & 7.52 & 26.28 & 66.20 & C \\
\hline & $2 \mathrm{Ck}$ & $108+$ & $2.5 Y 5 / 2$ & Masif; ÇY-ÇP & 7.52 & 35.14 & 57.34 & $\mathrm{C}$ \\
\hline \multirow{5}{*}{ P4 } & $A p$ & $0-19$ & $10 Y R 4 / 3$ & OOYKB; Y-P & 5.52 & 49.28 & 45.20 & sic \\
\hline & $\mathrm{A} 2 \mathrm{~d}$ & $19-48$ & $10 Y R 4 / 3$ & OOYKB; Y-P & 9.16 & 45.28 & 45.56 & sic \\
\hline & $\mathrm{C} 1$ & $48-86$ & $10 Y R 4 / 3$ & Masif; ÇY-ÇP & 7.52 & 45.28 & 47.20 & sic \\
\hline & $\mathrm{C} 2$ & $86-104$ & 10YR $3 / 2$ & Masif; ÇY-ÇP & 7.16 & 37.28 & 55.56 & $\mathrm{C}$ \\
\hline & $\mathrm{C} 3$ & $104+$ & $2.5 Y 5 / 3$ & Masif; ÇY-ÇP & 9.52 & 40.92 & 49.56 & sic \\
\hline \multirow{5}{*}{ P5 } & $A p$ & $0-9$ & $2.5 Y 4 / 2$ & KOYKB; ÇY-ÇP & 8.88 & 32.92 & 58.20 & $\mathrm{C}$ \\
\hline & $A 2 d$ & $9-29$ & $2.5 Y 3 / 1$ & KOYKB; ÇY-ÇP & 7.88 & 30.92 & 61.20 & C \\
\hline & $\mathrm{ACg}$ & $29-45$ & $2.5 Y 5 / 2$ & Masif; ÇY-ÇP & 8.24 & 32.56 & 59.20 & C \\
\hline & $\mathrm{C} 1 \mathrm{k}$ & $45-67$ & 2.5 Y $5 / 3$ & Masif; ÇY-ÇP & 3.88 & 33.92 & 62.20 & C \\
\hline & $\mathrm{C} 2 \mathrm{k}$ & $67+$ & 2.5 Y $5 / 3$ & Masif; ÇY-ÇP & 6.24 & 32.56 & 61.20 & $\mathrm{C}$ \\
\hline \multirow{7}{*}{ P6 } & $A p$ & $0-15$ & $2.5 Y 4 / 3$ & OOYKB; AY-AP & 9.52 & 52.92 & 37.56 & $\mathrm{SiCL}$ \\
\hline & $\mathrm{A} 2 \mathrm{~d}$ & $15-28$ & $2.5 Y 5 / 3$ & Masif; AY-AP & 11.16 & 51.28 & 37.56 & $\mathrm{SiCL}$ \\
\hline & $\mathrm{AC1}$ & $28-50$ & $2.5 Y 4 / 3$ & Masif; AY-AP & 11.52 & 57.28 & 31.20 & $\mathrm{SiCL}$ \\
\hline & $\mathrm{AC2}$ & $50-77$ & $2.5 Y 4 / 3$ & Masif; AY-AP & 9.52 & 54.92 & 35.56 & $\mathrm{SiCL}$ \\
\hline & $\mathrm{C} 1$ & $77-105$ & $2.5 Y 6 / 4$ & Masif; Y-P & 9.88 & 48.92 & 41.20 & $\mathrm{SiC}$ \\
\hline & $\mathrm{C} 2$ & $105-145$ & $2.5 Y 6 / 4$ & Masif; Y-P & 11.02 & 45.78 & 43.20 & $\mathrm{SiC}$ \\
\hline & $\mathrm{C} 3$ & $145+$ & $2.5 Y 5 / 4$ & Masif; Y-P & 11.24 & 47.56 & 41.20 & $\mathrm{SiC}$ \\
\hline \multirow{8}{*}{ P7 } & $\mathrm{Ap}$ & $0-18$ & $10 Y R$ 4/3 & OOYKB; AY-AP & 25.52 & 49.28 & 25.2 & $\mathrm{~L}$ \\
\hline & $\mathrm{A} 2$ & $18-33$ & $10 Y R 4 / 3$ & ZKYKB; AY-AP & 44.52 & 33.28 & 22.2 & $\mathrm{~L}$ \\
\hline & $A C$ & $33-54$ & $10 Y R 4 / 3$ & Masif; AY-AP & 48.24 & 23.56 & 28.2 & $\mathrm{SCL}$ \\
\hline & $\mathrm{CA}$ & $54-70$ & $10 Y R 5 / 3$ & Masif; AY-AP & 19.88 & 54.92 & 25.2 & $\mathrm{SiL}$ \\
\hline & $\mathrm{C} 1$ & $70-89$ & $2.5 Y 4 / 3$ & Masif; AY-AP & 31.88 & 43.92 & 24.2 & $\mathrm{~L}$ \\
\hline & $\mathrm{C} 2$ & $89-112$ & $2.5 Y 5 / 3$ & Masif; AY-AP & 21.88 & 45.92 & 32.2 & $\mathrm{CL}$ \\
\hline & $\mathrm{C} 3$ & $112-134$ & $2.5 Y 5 / 3$ & Masif; ÇY-ÇP & 11.88 & 47.92 & 40.2 & $\mathrm{SiC}$ \\
\hline & $\mathrm{C} 4$ & $134+$ & $2.5 Y 5 / 3$ & Masif; ÇY-ÇP & 7.88 & 51.92 & 40.2 & $\mathrm{SiC}$ \\
\hline \multirow{4}{*}{ P8 } & $A p$ & $0-15$ & $10 Y R$ 4/3 & OOYKB; Y-P & 36.80 & 34.64 & 28.56 & $\mathrm{CL}$ \\
\hline & $\mathrm{A} 2$ & $15-29$ & $10 Y R 4 / 3$ & OOYKB; Y-P & 25.52 & 39.92 & 34.56 & $\mathrm{CL}$ \\
\hline & $\mathrm{C} 1$ & $29-52$ & 10YR $4 / 3$ & Masif; AY-AP & 35.16 & 35.28 & 29.56 & $\mathrm{CL}$ \\
\hline & $\mathrm{C} 2$ & $52+$ & $10 Y R 4 / 4$ & Masif; AY-AP & 27.80 & 37.64 & 34.56 & $\mathrm{CL}$ \\
\hline
\end{tabular}

Strüktür: KOYKB; kuvvetli orta yarı köşeli blok. OOKB: Orta orta yarı köşeli blok OOYKB: Orta orta yarı köşeli blok.

ZOYKB; Zayıf orta yarı köşeli blok. ZKYKB; Zayıf küçük yarı köşeli blok

Yaş Kıvam: AY-AP: Az yapışkan az plastik. Y-P; Yapışkan plastik. ÇY-ÇP: Çok yapışkan çok plastik 
Çizelge 3. Toprak profillerinin kimyasal özellikleri

Table 3. Chemical properties of soil profiles

\begin{tabular}{|c|c|c|c|c|c|c|c|c|c|c|}
\hline $\begin{array}{l}\text { Profil } \\
\text { Profile }\end{array}$ & $\begin{array}{l}\text { Horizon } \\
\text { Horizon }\end{array}$ & $\begin{array}{l}\text { Derinlik } \\
(\mathrm{cm}) \\
\text { Depth } \\
(\mathrm{cm})\end{array}$ & $\begin{array}{l}\mathrm{pH} \\
\mathrm{pH}\end{array}$ & $\begin{array}{c}\text { EC } \\
(\%) \\
E C \\
(\%)\end{array}$ & $\begin{array}{l}\text { Kireç } \\
(\%) \\
\text { Lime } \\
(\%)\end{array}$ & $\begin{array}{c}\text { Organik } \\
\text { Madde } \\
(\%) \\
\text { Organic } \\
\text { Matter } \\
(\%)\end{array}$ & $\begin{array}{c}\mathrm{K} \\
\text { meq } 100 \mathrm{~g}^{-1} \\
\mathrm{~K} \\
\text { meq } 100 \mathrm{~g}^{-}\end{array}$ & $\begin{array}{c}\mathrm{Na} \\
\mathrm{meq} / 100 \mathrm{~g}^{-1} \\
\mathrm{Na} \\
\mathrm{meq} / 100 \mathrm{~g}^{-}\end{array}$ & $\begin{array}{c}\mathrm{Ca}+\mathrm{Mg} \\
\mathrm{meq} / 100 \mathrm{~g}^{-1} \\
\mathrm{C} a+\mathrm{Mg} \\
\mathrm{meq} / 100 \mathrm{~g}^{-1}\end{array}$ & $\begin{array}{c}\text { KDK } \\
\text { meq } / 100 \mathrm{~g}^{-1} \\
\text { CEC } \\
\text { meq } / 100 \mathrm{~g}^{-1}\end{array}$ \\
\hline \multirow{5}{*}{$\mathrm{P} 1$} & $\mathrm{Ap}$ & $0-14$ & 7.37 & 0.013 & 23.01 & 2.83 & 1.61 & 0.22 & 32.27 & 34.10 \\
\hline & $\mathrm{A} 2$ & $14-31$ & 7.41 & 0.013 & 23.09 & 1.94 & 1.01 & 0.20 & 31.21 & 32.41 \\
\hline & $A C$ & $31-49$ & 7.38 & 0.010 & 23.09 & 1.79 & 0.71 & 0.19 & 47.76 & 48.66 \\
\hline & $\mathrm{C} 1$ & $49-75$ & 7.60 & 0.009 & 27.12 & 1.19 & 0.57 & 0.28 & 35.04 & 35.89 \\
\hline & $\mathrm{C} 2$ & $75+$ & 7.55 & 0.009 & 30.38 & 1.04 & 0.48 & 0.23 & 30.82 & 31.53 \\
\hline \multirow{6}{*}{ P2 } & $A p$ & $0-17$ & 7.39 & 0.015 & 28.94 & 3.28 & 1.32 & 0.34 & 48.81 & 50.47 \\
\hline & $A 2 d$ & $17-26$ & 7.66 & 0.007 & 29.62 & 1.41 & 0.70 & 0.36 & 35.22 & 36.27 \\
\hline & $A C$ & $26-42$ & 7.69 & 0.008 & 27.42 & 2.01 & 0.64 & 0.60 & 37.01 & 38.24 \\
\hline & $\mathrm{C} 1$ & $42-66$ & 7.67 & 0.008 & 29.17 & 1.64 & 0.56 & 0.59 & 35.19 & 36.35 \\
\hline & $\mathrm{C} 2$ & $66-108$ & 7.80 & 0.009 & 30.68 & 1.34 & 0.54 & 0.83 & 33.22 & 34.58 \\
\hline & $\mathrm{C} 3$ & $108+$ & 7.87 & 0.011 & 31.98 & 0.89 & 0.51 & 1.70 & 31.79 & 34.00 \\
\hline \multirow{6}{*}{ P3 } & $A p$ & $0-18$ & 7.52 & 0.013 & 24.76 & 3.35 & 1.16 & 0.34 & 48.79 & 50.29 \\
\hline & $A 2 d$ & $18-38$ & 7.48 & 0.013 & 24.61 & 3.13 & 0.65 & 0.16 & 45.87 & 46.69 \\
\hline & $A C$ & $38-58$ & 7.50 & 0.011 & 18.00 & 2.53 & 0.63 & 0.19 & 50.70 & 51.52 \\
\hline & $\mathrm{C} 1$ & $58-77$ & 7.42 & 0.007 & 12.91 & 1.34 & 0.59 & 0.19 & 54.50 & 55.28 \\
\hline & $\mathrm{C} 2$ & $77-108$ & 7.19 & 0.009 & 10.67 & 1.94 & 0.65 & 0.25 & 51.81 & 52.71 \\
\hline & $2 \mathrm{Ck}$ & $108+$ & 7.36 & 0.014 & 20.43 & 2.83 & 0.54 & 0.20 & 41.89 & 42.63 \\
\hline \multirow{5}{*}{ P4 } & $A p$ & $0-19$ & 7.48 & 0.007 & 30.61 & 1.49 & 0.75 & 0.21 & 29.61 & 30.56 \\
\hline & $\mathrm{A} 2 \mathrm{~d}$ & $19-48$ & 7.49 & 0.009 & 29.77 & 2.23 & 0.47 & 0.20 & 30.33 & 31.00 \\
\hline & $\mathrm{C} 1$ & $48-86$ & 7.66 & 0.010 & 29.55 & 1.19 & 0.44 & 0.24 & 32.40 & 33.08 \\
\hline & $\mathrm{C} 2$ & $86-104$ & 7.53 & 0.011 & 32.96 & 1.49 & 0.43 & 0.50 & 29.98 & 30.92 \\
\hline & C3 & $104+$ & 7.52 & 0.010 & 32.89 & 0.89 & 0.44 & 0.51 & 30.28 & 31.23 \\
\hline \multirow{5}{*}{ P5 } & $A p$ & $0-9$ & 7.36 & 0.009 & 24.53 & 3.42 & 0.96 & 0.11 & 40.26 & 41.33 \\
\hline & $A 2 d$ & $9-29$ & 7.47 & 0.010 & 22.63 & 2.53 & 0.75 & 0.25 & 52.49 & 53.49 \\
\hline & $\mathrm{ACg}$ & $29-45$ & 7.32 & 0.009 & 27.80 & 1.04 & 0.65 & 0.21 & 46.91 & 47.76 \\
\hline & $\mathrm{C} 1 \mathrm{k}$ & $45-67$ & 7.50 & 0.010 & 34.18 & 0.89 & 0.52 & 0.25 & 44.87 & 45.64 \\
\hline & $\mathrm{C} 2 \mathrm{k}$ & $67+$ & 7.61 & 0.011 & 32.81 & 0.74 & 0.49 & 0.21 & 39.81 & 40.51 \\
\hline \multirow{7}{*}{ P6 } & $A p$ & $0-15$ & 7.69 & 0.010 & 30.53 & 2.38 & 1.06 & 0.08 & 25.56 & 26.69 \\
\hline & $A 2 d$ & $15-28$ & 7.59 & 0.009 & 30.68 & 1.79 & 0.67 & 0.10 & 29.76 & 30.52 \\
\hline & $\mathrm{AC1}$ & $28-50$ & 7.75 & 0.006 & 32.36 & 1.19 & 0.35 & 0.10 & 27.11 & 27.55 \\
\hline & $A C 2$ & $50-77$ & 7.74 & 0.006 & 30.84 & 1.34 & 0.40 & 0.14 & 30.45 & 30.98 \\
\hline & $\mathrm{C} 1$ & 77-105 & 7.85 & 0.007 & 32.58 & 1.49 & 0.43 & 0.23 & 34.57 & 35.23 \\
\hline & $\mathrm{C} 2$ & $105-145$ & 7.58 & 0.009 & 31.82 & 0.60 & 0.41 & 0.18 & 32.62 & 33.21 \\
\hline & $\mathrm{C} 3$ & $145+$ & 7.57 & 0.010 & 32.28 & 0.89 & 0.40 & 0.23 & 31.83 & 32.46 \\
\hline \multirow{8}{*}{ P7 } & $A p$ & $0-18$ & 7.37 & 0.014 & 31.48 & 3.13 & 0.43 & 0.39 & 26.24 & 27.07 \\
\hline & $\mathrm{A} 2$ & $18-33$ & 7.42 & 0.014 & 32.43 & 2.98 & 0.34 & 0.42 & 27.88 & 28.68 \\
\hline & $A C$ & $33-54$ & 7.65 & 0.013 & 32.81 & 2.68 & 0.35 & 0.36 & 30.19 & 30.91 \\
\hline & $\mathrm{CA}$ & $54-70$ & 7.71 & 0.010 & 33.19 & 2.53 & 0.36 & 0.41 & 30.73 & 31.50 \\
\hline & $\mathrm{C} 1$ & $70-89$ & 7.57 & 0.013 & 31.14 & 2.38 & 0.33 & 0.38 & 31.14 & 31.85 \\
\hline & $\mathrm{C} 2$ & $89-112$ & 7.69 & 0.010 & 33.87 & 2.08 & 0.35 & 0.38 & 30.96 & 31.68 \\
\hline & $\mathrm{C} 3$ & $112-134$ & 7.68 & 0.010 & 32.89 & 1.64 & 0.39 & 0.32 & 35.90 & 36.61 \\
\hline & $\mathrm{C} 4$ & $134+$ & 7.68 & 0.010 & 34.25 & 0.89 & 0.40 & 0.40 & 46.07 & 46.87 \\
\hline \multirow{4}{*}{ P8 } & Ap & $0-15$ & 7.48 & 0.118 & 22.94 & 2.23 & 0.74 & 0.11 & 31.38 & 32.23 \\
\hline & $\mathrm{A} 2$ & $15-29$ & 7.47 & 0.101 & 23.01 & 2.23 & 0.69 & 0.12 & 39.59 & 40.40 \\
\hline & $\mathrm{C} 1$ & $29-52$ & 7.43 & 0.008 & 24.53 & 1.64 & 0.50 & 0.24 & 33.84 & 34.58 \\
\hline & $\mathrm{C} 2$ & $52+$ & 7.47 & 0.007 & 24.15 & 1.12 & 0.47 & 0.14 & 37.98 & 38.58 \\
\hline
\end{tabular}

Araziden noktasal veriler seklinde elde edilen pedolojik değişkenlerin haritalandırılmasında öncelikle bu değişkenlere uygun veri tabanı hazırlanmıştır. Çalışma alanı içerisinde bir birine $250 \mathrm{~m} \times 250 \mathrm{~m}$ mesafede bulunan 259 adet kontrol sondası atılmıştır (Şekil 3). Bu kontrol sondalarından elde edilen dönüştürülmüş formattaki sayısal veriler ArcGIS 10.2 yazılımı ile birlikte ordinary kriging enterpolasyon ve üssel model ile (Exponatial) değerlendirmeye alınmıştır. Bu kapsamda, bireysel toprak özelliklerinin kendi aralarındaki ve aynı özelliklerin, farklı konumsallıklardaki bağımlılık derecelerinin hesaplanması suretiyle, değişkenlerin birbirleriyle olan ilişkilerini ortaya koyan ve noktasal değerler yerine incelenen değişkenin belirlenmiş bir alan üzerindeki ortalama değerinin kullanılmasını sağlayan interpolasyon yöntemi uygulanmıştır. Interpolasyon yöntemi sonucunda seri dağılım haritası oluşturulmuştur (Şekil 4). Şekil 3'de gösterilen seri dağılım haritası sonuçlarına göre; araştırma alanında en fazla yayılım alanı Kelbük serisi topraklarında (570.09 ha), en az yayılım alanı ise Batem 2 seri topraklarında (44.03 ha) tespit edilmiştir (Çizelge 4). Jeoistatistiksel yöntemler kullanılarak tarımsal üretimi kısıtlayıcı 
toprak özelliklerine sahip toprak serilerinin yayılım alanlarını gösteren seri haritası sayesinde işgücü, zaman ve maliyetten önemli ölçüde tasarruf sağlanmıştır. Çalışma alanı sınırları içerisinde Solak Köyü yerleşkesi, Ekspo, Aksu Çayı ve Tehnelli derelerinin bulunduğu 200.06 ha çalışma alanı dışında tutulmuştur.

Çizelge 4. Toprak serilerinin alansal ve oransal dağılımları

Figure 4. Spatial and proportional distributions of soil series

\begin{tabular}{clll}
\hline $\begin{array}{c}\text { Profil No } \\
\text { Profile } \\
\text { Number }\end{array}$ & $\begin{array}{l}\text { Seri Adı } \\
\text { Seri Name }\end{array}$ & $\begin{array}{l}\text { Alan } \\
\text { (ha) } \\
\text { Area } \\
\text { (ha) }\end{array}$ & $\begin{array}{l}\text { Oran } \\
(\%) \\
\text { Ratio } \\
(\%)\end{array}$ \\
\hline 1 & Batem 1 & 101.01 & 6.22 \\
2 & Ekspo & 130.98 & 8.06 \\
3 & Mısnar & 81.53 & 5.02 \\
4 & Körcegözler & 162.22 & 9.98 \\
5 & Atçayırı & 149.16 & 9.18 \\
6 & Kelbük & 570.09 & 35.08 \\
7 & Solak & 186.26 & 11.46 \\
8 & Batem 2 & 44.03 & 2.71 \\
\end{tabular}

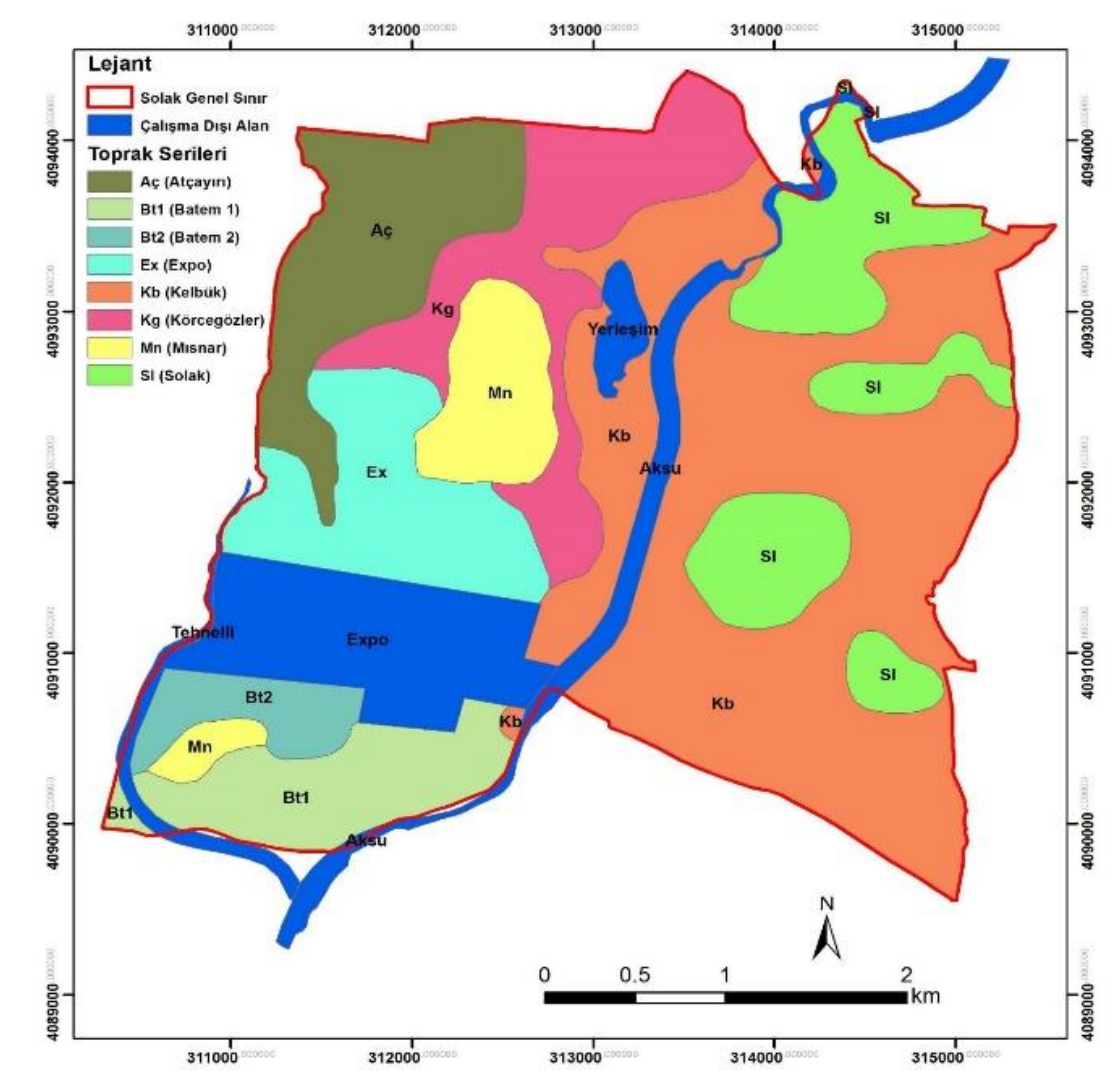

Şekil 4. Çalışma alanı içerisindeki toprak serilerinin dağılımı

Figure 4. Distribution of soil series within the study area

\section{Sonuçlar}

Araştırma alanında yapılan detaylı toprak etüt ve haritalama çalışmaları sonucunda, taşkın düzlüğü, nehir sırtı ve yan dere alüvyalleri fizyografik ünitelerinde belirlenen 8 farklı toprak serilerinin morfolojik, fiziksel ve kimyasal özellikleri tespit edilmiştir. Bu kapsamda tespit edilen 8 farklı toprak serisinde sınırlı toprak gelişimiyle $A / C$ horizon diziliminde olduğu belirlenmiştir. Çalışma alanında yayııım gösteren topraklardan taşkın düzlüğü fizyoğrafyasında gelişen özellikle P2, P3 ve P5 profillerindeki yüksek kil ve kireç içeriği, düşük geçirgenlik ve zaman zaman yükselen taban suları sorunları tespit edilmiştir. Diğer taraftan nehir sırtı ve yan dere aluviyalleri üzerinde gelişen topraklarda göreceli olarak yüksek kum/silt içeriği ve düşük 
KDK içeriği tespit edilmiştir. Özellikle yüksek kireç içeren topraklarının yüksek $\mathrm{pH}$ değerleri ile $\mathrm{PO}_{4}$ formundaki fosforun, bu topraklarda bolca bulunan kalsiyum ve magnezyum iyonları ile reaksiyona girerek zor çözünür ve bitkiler

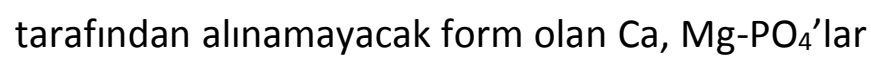
şeklinde çökeldiği ve alınabilir formalarında azalmalar olabilecektir. Topraklardaki yüksek kireç içeriğine bağlı olarak mikro element noksanlığının da çıkması kuvvetli ihtimal olarak görülmektedir. $\mathrm{Bu}$ nedenle topraktan mikro element uygulamalarına ilaveten yapraktan uygulamalarda oldukça önemlidir. Özellikle P5 profilinin yayılım gösterdiği alanlarda taban suyunun belirli dönemlerde $30 \mathrm{~cm}$ yüzeye kadar yaklaştığını gösteren pas lekeleri gözlemlenmiştir. Dönemlik olarak toprak yüzeyine yakın seyreden taban suyu dikkate alındığında P2, P3 ve P5 profillerinin yayılım gösterdiği alanlarda her hangi bir meyve bahçesinin tesis edilmemesi olası ekonomik kayıpların önüne geçecektir. Yoğun kil içeriğine bağlı toprak sıkışması sonucunda topraktaki ideal hava dengesinin azalmasını engellemek veya yoğun kum/silt içeriğine bağı olarak toprak strüktürünün gelişmesine de katkı amacıyla belirli periyodik dönemlerde katı ve sıvı organik gübre ilavesi yapılmadır. Araştırma alanı içerisindeki tarımsal üretimi kısıtlayan olumsuzluklarının en aza indirilmesi ve bu toprakların sürdürülebilir kullanımlarının sağlanması amacıyla söz konusu fiziksel ve kültürel bazı önlemlerin alınması tarımsal üretimi ve sürdürülebilir toprak kalitesini artıracaktır.

\section{Ekler}

Bu çalışma, FBA-2016-1536 numaralı Araştırma Projesinin bir bölümüdür. Katkılarından dolayı Akdeniz Üniversitesi Bilimsel Araştırma Projeleri Yönetim Birimine teşekkür ederiz.

\section{Çıkar Çatışması Beyanı: Makale yazarları} aralarında herhangi bir çıkar çatışması olmadığını beyan ederler.

\section{Kaynaklar}

Altunbaş, S., ve Sarı, M. (2011). Kurutulan Kestel gölünden kazanılan toprakların bazı özellikleri ile üretim potansiyelleri arasındaki ilişkiler. Akdeniz Üniversitesi. Ziraat Fakültesi Dergisi, 24(1), 61-65.

Black, C. A. (1965). Methods of Soil Analysis Part 2, Amer. Society of Agronomy Inc., Publisher Madisson, Wilconsin, U.S.A., 1372-1376.

Bouyoucos, G. J. (1955). A recalibration of the hydrometer method for making mechanical analysis of the soils, Agronomy Journal, 4 (9), 434.

Dengiz, O., ve Gülser, C. (2014). Farklı fluviyal depozitler üzerinde oluşmuş toprakların dağılım alanlarının belirlenmesi ve sınıflaması. Türkiye Tarımsal Araştırmalar Dergisi, 1, 9-17.

Dinç, U. ve Şenol, S. (1990). Toprak etüt ve haritalama. Çukurova Üniversitesi Ziraat Fakültesi Ders Kitabı, No:66, S.108. Adana.

Dinç, U., Şenol, S. (2013). Toprak etüd ve haritalama. Çukurova Üniversitesi Ziraat Fakültesi Genel Yayın No: 161, Ders Kitapları Yayın No: A-50 Çukurova Üniversitesi Ziraat Fakültesi Ofset Atölyesi, Adana Sy: 235.

Evliya, H. (1964). Kültür bitkilerinin beslenmesi. Ankara. Üniversitesi Ziraat Fakültesi Yayınları, Yayın no:36, 292- 294, Ankara.

Gözükara, G. (2019). Eski göl tabanlarındaki zamansal ve mekansal değişimlerin toprak oluşumuna etkileri; Burdur Göl Havzası Örneği (Doktora Tezi). Akdeniz Üniversitesi, Fen Bilimleri Enstitüsü, Antalya.

Gözükara, G., Altunbaş, S., Sarı, M., 2019. Mekansal değişimin alüviyal fanlar üzerinde oluşan toprakların özelliklerine etkisi. Mediterrenean Agricultural Scieces. 32(3):425-435.

Gözükara, G., Altunbaş, S., Sarı, M. 2020. Zamansal ve mekansal değişimlerin eski göl tabanlarındaki toprak oluşumu, gelişimi ve morfolojisi üzerine etkisi. Harran Tarım ve Gıda Bilimleri Dergisi. 24(1):96-110.

Hızalan, E. (1969). Toprak etüt ve haritalama I. A.Ü. Ziraat Fakültesi Yayınları 379, $218 \mathrm{~S}$.

Jackson, M. C. (1967). Soil chemical analysis. Prentice Hall of India Private'Limited, New Delhi.

Jenkins, D.A., and Jones, R.G.W. (1980). Trace Elements in Rock, Soil, Plant and Animal: Introduction. In: Davies, B.E. (Ed), Applied Soil Trace Elements. John Wiley and Son Ltd., pp. 1-20.

Kacar, B. (1995). Bitki ve toprağın kimyasal analizleri; Toprak Analizleri. A. Ü. Ziraat Fakültesi Geliştirme Vakfı Yayınları No: 3.

Mutlu, H.H. (2010). Eski konya gölü kuvaterner terasları üzerinde oluşan toprakların jeokimyasal özellikleri ve ayrışma oranları (Doktora Tezi). Selçuk Üniversitesi, Fen Bilimleri Enstitüsü, Konya.

Osher, J.L. and Buol, W.S. (1998). Relationship of soil properties to parent material and landscape position in eastern madre de dios. Peru. Geoderma, 83, 143166.

Owliaie, H., Ghiri, M.N. and Shakeri, S. (2018). Soillandscape relationship as indicated by pedogenesis data on selected soils from Southwestern, Iran. Eurasian Journal of Soil Science, 7(2), 167-180.

Sarı, M., Altunbaş, S., Sönmez, N.K. ve Emrahoğlu, E.I. 
(2003). Farklı fizyografik üniteler üzerinde yer alan eski Manay göl alanı topraklarının özellikleri ve potansiyel üretkenlikleri. Akdeniz Üniversitesi Ziraat Fakültesi Dergisi, 16(1), 7-17.

Sarı, M., Sönmez, N.K., Altunbaş, S. (2009). Aksu araştırma ve uygulama istasyonu topraklarının morfolojik, fiziksel ve kimyasal özellikleri, Akdeniz Üniversitesi Ziraat Fakültesi Dergisi, 22(2), 157-168.

Sarı, M. (2015). Taşınmış anamateryal ile yer şekilleri arasındaki ilişkiler. Şenol, S., Küsek, G., Sarı, M., Kurucu, Y. (Editorler), Toprak Etüd Haritalama El Kitabı. Tarım Arazileri Değerlendirme Dairesi Başkanlığı. S.52-109.

Soil Survey Staff, 2013. Kellogg Soil Survey Laboratory Methods Manual. Soil Survey Investigations Report No. 42, Version 5.0. R. Burt and Soil Survey Staff (ed.). Lincoln NE: U.S. Department of Agriculture, Natural Resources Conservation Service.
Soil Survey Staff. (2014). Keys to Soil Taxanomy. Twelfth Edition Edition, United States Department of Agriculture, Natural Resources Conservation Service ISBN 0-16-048848-6. Washington DC.

Soil Survey Laboratory, (2004). Soil Survey Laboratory Methods Manual. USDA Natural Resources Conservation Service. Soil Survey Investigations Report No 42. Washington D.C., USA.

Şenol, S. (2000). Pedo-Jeomorfoloji. Çukurova Üniversitesi Ziraat Fakültesi Ders Notları, s.33.

Şenol, S. (2015). Toprak etüt haritalama işlem ve metodolojisi. Şenol, S., Küsek, G., Sarı, M., Kurucu, Y. (Editorler), Toprak Etüd Haritalama El Kitabı. Tarım Arazileri Değerlendirme Dairesi Başkanlığı. S.52-109.

Şimşek, O., Altunbaş, S., Demirel, B.Ç., Gözükara, G., 2020. Alüviyal fizyografyalar üzerinde gelişen farklı topraklarda arazi değerlendirme çalışmaları. Mediterrenean Agricultural Scieces. 33(1):129-135. 